\section{Chapter}

[3]

\title{
Impacts of agricultural pollutants on water resources and their management
}

\author{
Gaurav Chaturvedi*, Moumita Chakraborty and Ardeep
}

G. B. Pant University of Agriculture and Technology, Pantnagar 263145, Uttarakhand, India

\begin{abstract}
Water pollution is a rising global challenge that has expanded in both developed and developing nations, discouraging the growth of the economy as well as the physical and environmental health of billions of individuals. Recognizing the significance of water, the 2030 Agenda for Sustainable Development has incorporated certain water quality mark that is needed to be attained in Sustainable Development Goal (SDGs) 6. Human settlements, industries, and agriculture are the main causes of water pollution. Water pollution in agriculture is complex and multidimensional, and its effective management requires a comprehensive package of responses. Such responses need to act on key drivers of agricultural expansion and intensification, such as unsustainable dietary shifts and food waste and loss; limit the export of pollutants from farms; protect water bodies from agricultural pollution loads, and help restore already-affected water bodies. Responses for influencing both farm and landscape-scale practices may include regulation; the use of economic instruments; education and awareness-raising; cooperative agreements; and research and innovation. Policies to change farmer behavior and incentivize the adoption of good practices are the key to prevent pollution at the source. Demonstrating the economic benefits to the farmers for adopting good practices has also been shown to be effective.
\end{abstract}

\section{Keywords}

Agricultural pollution, Sustainable development goal, Water pollution 


\section{Introduction}

Worldwide, the municipal wastewater that accounts for almost $80 \%$ in its raw and unprocessed form is ejected out into the aquatic bodies, the production houses and industries are solely responsible for discarding millions of tonnes of volatile organic compounds, poisonous solvents, toxic sludge, and other wastes into water bodies every year (WWAP, 2017). According to World Health Organization statistics, half of India's morbidity is water-related (WHO, 2012). Not only $70 \%$ of India's surface water resources but also an expanding percentage of the groundwater reserves are polluted by toxic, biological, organic, and inorganic pollutants due to indiscriminate dumping of commercial sewage, wastes arising from domestic household and agricultural pollutants.

These effluent sources pose a life-threatening danger for human utilization and also for other undertakings such as agriculture and commercial needs. Water pollution takes place when injurious substances are released into the water bodies in bulk volume causing harm to people and the environment. Besides human activities, natural events like volcanoes, earthquakes, and storms also bring about considerable changes in the quality of water and its ecological status. Agriculture alone makes up for $70 \%$ of water extraction globally, plays a vital role in degrading the water quality (UNEP, 2016). Greater quantities of agrochemicals, sediments, and saline drainage are poured out by the farms into aquatic bodies. The resultant pollutants pose an illustrated threat to aquatic ecosystems, the health of the people, and production activities. Pesticides, pathogens, nutrients, and sediments being the main agricultural donors to pollution of the water bodies are the primary challenges for controlling the same. Agriculture utilizes the largest percentage of fresh water on a global basis. The linked up agro food-processing units are also a notable cause of organic pollution in various countries. Aquaculture is now realized as the main issue in freshwater and marine environments, leading to eutrophication and destruction of the aquatic ecosystem. The vital public and environmental health aspects of global water quality trouble are highlighted below:

- $\quad$ Five million people die annually from water-borne diseases.

- Ecosystem dysfunction and loss of biodiversity.

- Contamination of marine ecosystems from land-based activities.

- Contamination of groundwater resources.

\section{Impacts of agricultural pollutants on water quality}

The pesticides, nutrients, salts, organic carbon, and drug residues mainly contribute to water pollution. Table 1 shows the relative contributions of these pollutants to water-quality degradation. The importance of different forms of agricultural pollution varies with individual situations, and negative impacts such as eutrophication (which may include sediments, nutrients, and organic matter) arise from combinations of stressors. Table 2 described various activities contributing to water pollution. 
Table 1. Relative contributions of these pollutants to water-quality degradation.

\begin{tabular}{|c|c|c|c|c|}
\hline \multirow{2}{*}{$\begin{array}{l}\text { Pollutant } \\
\text { category }\end{array}$} & \multirow[t]{2}{*}{ Indicators/examples } & \multicolumn{3}{|c|}{ Relative contribution by } \\
\hline & & Crops & Livestock & Aquaculture \\
\hline Nutrients & $\begin{array}{l}\text { Primarily nitrogen and phosphorus present in } \\
\text { chemical and organic fertilizers as well as } \\
\text { animal excreta and normally found in water as } \\
\text { nitrate, ammonia or phosphate }\end{array}$ & $* * *$ & $* * *$ & * \\
\hline Pesticides & $\begin{array}{l}\text { Herbicides, insecticides, fungicides and } \\
\text { bactericides, including organophosphates, } \\
\text { carbamates, pyrethroids, organochlorine } \\
\text { pesticides and others (many, such as DDT, are } \\
\text { banned in most countries but are still being } \\
\text { used illegally and persistently) }\end{array}$ & $* * *$ & - & - \\
\hline Salts & $\begin{array}{l}\text { E.g. ions of sodium, chloride, potassium, } \\
\text { magnesium, sulphate, calcium and bicarbonate. } \\
\text { Measured in water, either directly as total } \\
\text { dissolved solids or indirectly as electric } \\
\text { conductivity }\end{array}$ & $* * *$ & * & * \\
\hline Sediment & $\begin{array}{l}\text { Measured in water as total suspended } \\
\text { solids or nephelometric turbidity units } \\
\text { - especially from pond drainage during } \\
\text { harvesting }\end{array}$ & $* * *$ & $* * *$ & * \\
\hline $\begin{array}{l}\text { Organic } \\
\text { matter }\end{array}$ & $\begin{array}{l}\text { Chemical or biochemical oxygen- demanding } \\
\text { substances (e.g. organic materials such as plant } \\
\text { matter and livestock excreta), which use up } \\
\text { dissolved oxygen in water when they degrade }\end{array}$ & * & $* * *$ & $* *$ \\
\hline Pathogens & $\begin{array}{l}\text { Bacteria and pathogen indicators. E.g. } \\
\text { Escherichia coli, total coliforms, faecal coliforms } \\
\text { and enterococci }\end{array}$ & * & $* * *$ & * \\
\hline Metals & $\begin{array}{l}\text { E.g. selenium, lead, copper, mercury, arsenic } \\
\text { and manganese }\end{array}$ & * & * & * \\
\hline $\begin{array}{l}\text { Emerging } \\
\text { pollutants }\end{array}$ & $\begin{array}{l}\text { E.g. drug residues, hormones and feed addi- } \\
\text { tives }\end{array}$ & - & $* * *$ & $* *$ \\
\hline
\end{tabular}

Nutrients: In crop production, water pollution from nutrients occurs when fertilizers are applied at a greater rate than they are fixed by soil particles or exported from the soil profile (e.g. by plant uptake or when they are washed off from the soil surface before plants can take them up). Excess nitrogen and phosphates can leach into groundwater or move via surface runoff into waterways. Phosphate is not as soluble as nitrate and ammonia and tends to get adsorbed onto soil particles and enter water bodies through soil erosion. In livestock production, feedlots are often located on the banks of watercourses so 
Table 2. Impacts of various agricultural activities on surface and groundwater.

\begin{tabular}{|c|c|c|}
\hline \multirow{2}{*}{$\begin{array}{l}\text { Agricultural } \\
\text { activity }\end{array}$} & \multicolumn{2}{|l|}{ Impacts } \\
\hline & Surface water & Groundwater \\
\hline Tillage/ploughing & $\begin{array}{l}\text { Sediment/turbidity: phosphorus and pesticides carried } \\
\text { by sediments get adsorbed to the surface of sediment } \\
\text { particles; siltation of river beds and habitat loss, } \\
\text { spawning ground, etc. }\end{array}$ & \\
\hline Fertilizing & $\begin{array}{l}\text { Excess runoff of nutrients like phosphorus and nitrates } \\
\text { resulting in eutrophication, leading to excess growth of } \\
\text { algae which then leads to a condition of hypoxia of water } \\
\text { bodies and fish kills. }\end{array}$ & $\begin{array}{l}\text { High levels of nitrate leaching into } \\
\text { groundwater; pose a threat to } \\
\text { public health. }\end{array}$ \\
\hline $\begin{array}{l}\text { Manure } \\
\text { spreading }\end{array}$ & $\begin{array}{l}\text { Carried out as a fertilizer activity; spreading on frozen } \\
\text { ground results in high levels of contamination of } \\
\text { receiving waters by pathogens, metals, phosphorus and } \\
\text { nitrogen leading to eutrophication and potential } \\
\text { contamination. }\end{array}$ & $\begin{array}{l}\text { Contamination of groundwater, } \\
\text { especially by nitrogen }\end{array}$ \\
\hline Pesticides & $\begin{array}{l}\text { Runoff of pesticides leads to contamination of } \\
\text { surface water and biota; dysfunction of ecological system } \\
\text { in surface waters by loss of top predators due to growth } \\
\text { inhibition and reproductive failure; public health } \\
\text { impacts from eating contaminated fish. } \\
\text { Pesticides are carried as dust by wind over very long } \\
\text { distances and contaminate aquatic systems } 1000 \text { s of } \\
\text { miles away (e.g. tropical/subtropical pesticides found in } \\
\text { Arctic mammals). }\end{array}$ & $\begin{array}{l}\text { Some pesticides may each into } \\
\text { groundwater causing human } \\
\text { health problems from contaminat- } \\
\text { ed wells. }\end{array}$ \\
\hline $\begin{array}{l}\text { Feedlots/animal } \\
\text { corrals }\end{array}$ & $\begin{array}{l}\text { Contamination of surface water with many pathogens } \\
\text { (bacteria, viruses, etc.) leading to chronic public health } \\
\text { problems. Also, contamination by metals contained in } \\
\text { urine and faeces. }\end{array}$ & $\begin{array}{l}\text { Potential leaching of } \\
\text { nitrogen, metals, etc. to } \\
\text { groundwater. }\end{array}$ \\
\hline Irrigation & $\begin{array}{l}\text { Runoff of salts leading to salinization of surface waters; } \\
\text { runoff of fertilizers and pesticides to surface waters with } \\
\text { ecological damage, bioaccumulation in edible fish } \\
\text { species, etc. } \\
\text { High levels of trace elements such as selenium can occur } \\
\text { with serious ecological damage and potential human } \\
\text { health impacts. }\end{array}$ & $\begin{array}{l}\text { Enrichment of groundwater with } \\
\text { salts, nutrients (especially nitrate). }\end{array}$ \\
\hline Clear cutting & $\begin{array}{l}\text { Erosion of land, leading to high levels of turbidity in } \\
\text { rivers, siltation of bottom habitat, etc. Disruption and } \\
\text { change of hydrologic regime, often with loss of perennial } \\
\text { streams; causes public health problems due to loss of } \\
\text { potable water. }\end{array}$ & $\begin{array}{l}\text { Disruption of hydrologic regime, } \\
\text { often with increased surface runoff } \\
\text { and decreased groundwater } \\
\text { recharge; affects surface water by } \\
\text { decreasing flow in dry periods and } \\
\text { concentrating nutrients and } \\
\text { contaminants in surface water. }\end{array}$ \\
\hline Silviculture & $\begin{array}{l}\text { Broad range of effects: pesticide runoff and } \\
\text { contamination of surface water and fish; erosion and } \\
\text { sedimentation problems. }\end{array}$ & \\
\hline Aquaculture & $\begin{array}{l}\text { Release of pesticides (e.g. Tributyltin) and high levels of } \\
\text { nutrients to surface water and groundwater through } \\
\text { feed and faeces, leading to serious eutrophication. }\end{array}$ & \\
\hline
\end{tabular}


that (nutrient-rich) animal waste (e.g. urine) can be released directly into those watercourses. Manure is usually collected for use as organic fertilizer, which, if applied in excess, will lead to diffuse water pollution. In many cases, manure is not stored in contained areas and during significant rainfall events, it can be washed into watercourses via surface runoff. In fed aquaculture, the primary function of feed conversion and feed composition (faecal wastes) are the nourishing nutrient piles that are fed to the aquatic bodies. Residual feed in intensive fed aquaculture can be a noticeable donor to nutrient heaps in the water ecosystem. High-level nutrient loads along with other pollutants lead to the eutrophication of lakes, ponds and coastal waters that further leads to algae blooms that dominates and suppresses surrounding aquatic plants and animals. Nearly 415 coastal areas have been recognized worldwide to be undergoing eutrophication in some or the other form, 169 of which are hypoxic (WRI, 2008). The excess nutrients that get accumulated may also trigger adverse health effects, like blue-baby syndrome, due to excessive nitrate levels in drinking water.

Pesticides: In most countries, intensive application of pesticides and Insecticides are done (Schreinemachers and Tipraqsa, 2012). When not administered and managed properly, they can prove to be hazardous to water resources carrying carcinogenic and other toxic substances that can have a deleterious effect on human health. Pesticides may also affect biodiversity by killing weeds and insects, with negative impacts on the food chain. In developed countries, although considerable use of older broad-spectrum pesticides persists, the trend is towards the use of newer pesticides that are more selective and less toxic to humans and the environment and which require lower quantities per unit area to be effective. Nevertheless, millions of tonnes of active pesticide ingredients are used in agriculture (FAO, 2016). Acute pesticide poisoning causes significant human morbidity and mortality worldwide - especially in developing countries like India, where poor farmers often use highly hazardous pesticide formulations.

Salts: The production of brackish drainage and leaching water in agriculture has grown proportionally with the increase in irrigation in recent decades. Irrigation can mobilize salts accumulated in soils (leaching fractions), which are then transported by drainage water to receiving water bodies and cause salinization. Excessive irrigation can also raise water tables from saline aquifers and increase the seepage of saline groundwater into watercourses. Another major contribution to the salinization of coastal waters is by the entry of the salty seawater into aquifers - this result from unrestrained extracting of groundwater for agriculture (Mateo-Sagasta and Burke, 2010).

Major water-salinity problems have been reported in Argentina, Australia, China, India, Sudan, The United States of America, and many countries in Central Asia (Earthscan, 2011). In 2009, approximately 1.1 billion people lived in regions that had saline groundwater at shallow or intermediate depths (Van Weert et al., 2009). The geochemical cycles of major elements - such as carbon, nitrogen, phosphorus, and sulphur are altered due to high salt concentration that impacts the ecosystem (Herbert et al., 2015). Salinization can affect freshwater biota by causing changes within species and in community 
composition and can ultimately lead to biodiversity loss and migration. In general, when salinity increases, the biodiversity of microorganisms, algae, plants, and animals decline (Lorenz, 2014).

Sediments: Unsustainable land use and improper tillage and soil management in agriculture are increasing erosion and sediment runoff into rivers, lakes, and reservoirs, with massive quantities of soil lost and transported to water bodies every year. The global rate of erosion in croplands is estimated at 10.5 megagrams (Mg) per ha per year, which equals 193 kilograms of soil organic carbon per ha per year. Approximations for pastureland are lesser, at $1.7 \mathrm{Mg}$ per ha per year, which corresponds to 40.4 kilograms of soil organic carbon per ha per year. As per estimation, $43 \%$ of the agricultural sediment flux is in Asia (Doetterl et al., 2012). Higher rates of erosion occur in areas where precipitation is high, slopes are steep and vegetation cover is poor. Erosion is aggravated by overgrazing in pasturelands, by inappropriate ploughing on steep slopes, and more broadly, by deforestation, land clearing, and the degradation of riverine vegetation.

Sediment in river systems is a complex mixture of minerals and organic matter, potentially including physical and chemical pollutants. Sediments can cover and destroy fish spawning beds, clog fish gills, and reduce useful storage volume in reservoirs. Sedimentation can damage watercourses, choke streams, and make filtration necessary for municipal and irrigation water supplies. It can also affect delta formation and dynamics and limit the navigability of water bodies. Particles of clay and silt in sediment can adsorb many types of chemicals on their surfaces, including nutrients, heavy metals, and persistent organic pollutants. Sediment, therefore, is a key means by which such pollutants are transported to water bodies.

Organic matter: The organic matter obtained from the residual animal fodder and their excreta, animalprocessing units and crop residues acquired from poor agricultural practices is the prominent pollutants of water bodies. The wastes acquired from livestock have one of the highest biological oxygen demand (BOD). For example, pig slurry has a BOD in the range of 30,000-80,000 milligrams per litre, as compared to the typical BOD of domestic sewage that is in the range of 200-500 milligrams per litre (Steinfeld et al, 2006). Aquaculture can be considered as the main donor to organic effluent in water. The dissolved oxygen of the water bodies is then utilized by the microorganisms for the degradation of organic matter which results in the hypoxic condition of the aquatic body. The chances of eutrophication and algal blooms in lakes and coastal areas are further enhanced by the release of organic loads in them.

Pathogens: Several multicellular parasites and zoonotic microorganisms that can be injurious to human health are contained in livestock excreta. When food is irrigated using polluted water, pathogenic microorganisms can be food-borne or waterborne. Various pathogens have long lives and can live up to days or weeks in the excreta discharged onto land and thus polluting water bodies via runoff (Steinfeld et al, 2006; Dufour and Bartram, 2012). Bacteria like Escherichia coli, Clostridium botulinum, Salmonella spp. and parasitic protozoa like Microsporidia spp., Giardia lamblia, Cryptosporidium parvum are injurious to 
human health, all of these are reported every year to cause hundreds of thousands of infections (Christou, 2011).

Emerging pollutants: New agricultural pollutants such as antibiotics, vaccines, growth promoters, and hormones have emerged in the last two decades. These can reach water via leaching and runoff from livestock and aquaculture farms, as well as through the application of manure and slurries to agricultural land (OECD, 2012). Residues of heavy metals in agricultural inputs such as pesticides and animal feed are also emerging threats. Agriculture is not only a source of emerging pollutants, but it also contributes to the spread and reintroduction of such pollutants into aquatic environments through wastewater, (re)use for irrigation, and the application of municipal biosolids to land as fertilizers. An estimated 35.9 Mha of agricultural lands is subject to the indirect use of wastewater (Thebo et al., 2017). The potential risks to human health posed by exposure to emerging pollutants via contaminated agricultural products need attention.

\section{Mitigation of groundwater pollution caused by agricultural pollutants}

Water pollution in agriculture is complex and multidimensional, and its effective management requires a comprehensive package of responses. There arises the need for such responses to act upon the main drivers of intensification and expansion of agriculture, such as waste derived from food and unsustainable dietary shifts, restricting the emission of farm-level pollutants; safeguarding of water bodies from agricultural pollutant piles, and help restore already-affected water bodies. Responses for influencing both farms and landscape-scale practices may include regulation; the use of economic instruments; education and awareness-raising; cooperative agreements; and research and innovation.

Sustainable diets and reduced food waste: Different environmental footprints are dependent on the various diets consumed. There is an ever-increasing demand for food with high environmental footprints due to the rising population, such as meat from industrial farms, contributes to the depletion of water quality and unsustainable agricultural intensification. This can be changed, however. The more healthy and sustainable diets can be encouraged by accurate policies and incentives thereby neutralizing increases in food demand. For instance, a positive influence on dietary behaviour has been noticed by giving financial incentives such as taxes and subsidies on food and coupons to the consumers (Purnell et al., 2014).

Food losses and waste should be reduced as much as possible to bring food-production closer to actual food demand and to minimize the waste of resources and associated environmental impacts. About $25 \%$ of produced food is lost along the food supply chain. The production of this lost and wasted food accounts for $24 \%$ of the freshwater resources employed in crop production, $23 \%$ of total worldwide cropland zone, and $23 \%$ of total global fertilizer use (Kummu et al., 2012). Nitrogen pollution is very important for water quality, nitrogen released in the environment linked with global 
food waste is about 6.3 teragrams per year (Grizzetti et al., 2013), they also estimated that $12 \%$ of the water nitrogen diffuse pollution in agriculture is linked to food waste in the European Union. FAO has rigorously reviewed options for reducing food loss and waste (FAO, 2013, 2015).

Policy interventions: Well-known principles like "polluter pays" for reducing pollution are not easy to apply in a practical sense to the non-point agricultural pollution because recognizing the actual polluters is neither easy nor cheap. Typical regulatory instruments include prohibitions on the direct discharge of pollutants; limits on the marketing and sale of dangerous products; and restrictions on agricultural practices or the location of farms. Regulatory approaches require inspection or self-reporting to ensure compliance, with violations subject to penalties such as fines and compensation payments; however, enforcement remains a challenge. A combination of approaches like regulations, economic incentives, and information work well than regulations alone according to a study (OECD, 2008). Policies addressing water pollution in agriculture should be part of an overarching water policy framework at the national or river-basin scale, with all pollutants and polluters considered together. Policies to change farmer behaviour and incentivize the adoption of good practices are key to prevent pollution at the source. Such policies need to include (free) advisory services and training to farmers. Demonstrating the economic benefits to farmers of adopting good practices has also been shown to be effective. Benchmarking can promote behavioural change among farmers by showing them how they perform compared with their peers (without identifying the best and worst individuals). Benchmarking can be applied to the application of fertilizers, manure and slurries, and pesticides. A more subtle form of persuasion is the incorporation of environment modules into school curricula and involving students in raising environmental issues in their communities. Regulations to protect water quality need to be enforceable. Water-quality targets also need to be realistic and time-bound, and they need to balance the costs of adopting a solution and the benefits brought about by higher water quality. Typically, pollution prevention will be cheaper than the restoration of affected aquatic ecosystems. When formulating and implementing policies, priority should be given to major polluters and to water bodies where pollution is highest. The smart identification of pollution hotspots, for example in areas of major livestock concentrations, can help in prioritizing interventions. Finally, policies need to be coherent. Interventions aimed at increasing food production and farm income on the one hand and at mitigating pollution on the other should be mutually supportive - or at least not conflicting, although this may be hard (politically) to achieve in practice. For example, the subsidies frequently in place for agrochemicals do not act as an incentive for efficient use, and they encourage farming on more fragile lands. Effective interministerial cooperation mechanisms are required to increase policy coherence (Adelodun and Choi, 2020).

On-farm responses: In crop production, management practices for reducing the hazard of water pollution due to organic and inorganic fertilizers and pesticides involves limiting and optimizing the type, amount, and timing of applications to crops. Setting up protection zones along surface waterways, 
within farms, and in buffer zones around farms have been demonstrated to be viable in decreasing contamination of water bodies. The storage and discarding of pesticide waste and empty containers need to follow government safety guidelines. Also, efficient irrigation systems will decrease water return flows and therefore can significantly reduce the migration of fertilizers and pesticides to water bodies (Mateo-Sagasta and Burke, 2010). Contour ploughing and restrictions on the cultivation of steeply sloping soils are measures for reducing soil erosion (USEPA, 2003). Conservation agriculture has also proved very effective in erosion control. Manure management is one of the main concerns in livestock production and it needs to be stored, treated, handled, and disposed off or preferably reused safely. Manure treatments include composting and anaerobic fermentation, which can produce valuable organic fertilizers and soil conditioners. Intensive livestock operations such as feedlots that concentrate livestock need to be managed as point sources of pollution and should follow specific national regulations. The use of feed additives, hormones, and medicines should also adhere to national standards and international guidelines. In extensive livestock systems, overgrazing should be avoided to reduce land degradation and erosion. Aquaculture farms should adopt the right management practices to protect the surrounding aquatic environment, such as creating suitable production biomass based on the carrying capacity of the aquatic system; normalizing feed inputs to avoid excess feed; using fish drugs appropriately and abstaining from prohibited drugs; removing, treating and disposing of excessive nutrients in fishponds; and encouraging integrated multitrophic aquatic systems in which the waste of one species serves as a food source for another.

Off-farm responses: It is clear that the most effective way of mitigating pressures on aquatic ecosystems and rural ecosystems more generally is to avoid or limit the export of pollutants from where they are applied: the costs of mitigation increase greatly once pollutants are in an ecosystem. Simple off-farm techniques, such as the construction of riparian buffer strips or constructed wetlands, can cost-effectively reduce loads entering surface water bodies. The remediation of contaminated waters such as lakes and aquifers is a long-term and expensive undertaking and, in some cases, may not even be feasible. Buffer strips are a well-established technology. Vegetated filter strips at the margins of farms and along rivers are effective in decreasing concentrations of pollutants entering waterways. In agriculture and forestry, buffer zones usually comprise strips of vegetation that act as filters for sediment and their attached pollutants. Buffer strips can also perform other functions, such as stream shading, carbon sequestration, biomass production, channel stabilization, water purification and the provision of terrestrial and stream habitats, and provide cultural and recreational services. Constructed wetlands have been employed mainly to treat point-source wastewater, including urban and agricultural stormwater runoff. Such wetlands can also be used to treat agricultural drainage and remove sediments, nutrients, and other pollutants. The risks associated with brackish and saline agricultural drainage (return flows) need to be managed. Water management options include minimizing drainage by conserving water, treating drainage water (e.g. via evaporation ponds), and 
reuse (brackish and saline drainage water can be reused downstream directly or blended with freshwater). Such approaches require planning at the watershed scale to adapt agricultural practices and crops to increasing salt content at different cycles of reuse, which may include the production of prawns and fish using brackish or saline waters. Crops, vegetables, livestock, trees, and fish are managed collectively in the aquaculture-agriculture-forestry system that can elevate production sustainability, resource utilization efficiency, and environmental stability. To optimize the use of resources and reduce pollution, waste from one enterprise can be used as an input to another by utilizing integrated farming.

\section{Future research and recommendations}

There are many knowledge gaps concerning water pollution in agriculture, and more data and research are required. The contributions of crops, livestock, and aquaculture to water pollution are not well known, particularly in developing countries like India. Quantifying these contributions is essential if national governments are to understand the full extent of the problem and to develop meaningful and cost-effective responses. The polluter-pays principle cannot be applied if the source of pollution is unclear. Sustained research and modelling effort, supported by water quality monitoring, is needed to better understand pollutant pathways and the links between pollution causes and effects. The pathways of, and the health and environmental risks posed by, emerging agricultural pollutants such as animal hormones, antibiotics, and other pharmaceuticals are growing areas of research that require more attention. For example, greater understanding is needed of the contributions of animal medicines to the increasing problem of antimicrobial resistance among pathogens. Research cannot be conducted without data. Better data are needed for understanding process and detail in specific cases and also at a broader scale to understand the pressures on and state of aquatic systems and trends in their condition. Because many indicators are subject to temporal and spatial variability, adequate monitoring programs with appropriate sampling rates and density are key (but expensive) priorities for improvement. Research results need to be applied if they are to be effective in reducing pollution in agriculture.

\section{Conclusion}

Immediate action is required to avoid water resource pollution as well as the nature-friendly reuse of the enormous wastewater assimilated by the agriculture sector. It is possible to reduce agricultural water pollution with the help of enhanced nutrients, pesticides, crop, soil, and water management practices. There is a need to strengthen the database on the quantity of sediment, nutrient, and pesticides in runoff resulting from a basin or watershed. Increasing the number of monitoring stations for effective monitoring of agricultural/industrial water pollution is the hard-pressing need of the present times. India has well-defined wastewater discharge standards for the domestic and industrial 
sectors but there are no discharge standards for the pollution originating from the agriculture sector which needs to standardize. The policy for water pollution needs to deliver essential guidelines for monitoring and control of pollution resulting from industrial, agricultural, and other activities.

Conflict of interest: The author declares that there is no conflict of interest.

\section{References}

Adelodun, B. and Choi, K.S. (2020). Impact of food wastage on water resources and GHG emissions in Korea: A trend-based prediction modeling study. Journal of Cleaner Production, 271: 122562.

Christou, L. (2011). The global burden of bacterial and viral zoonotic infections. Clinical Microbiology and Infection, 17(3): 326-330.

Doetterl, S., Van Oost, K. and Six, J. (2012). Towards constraining the magnitude of global agricultural sediment and soil organic carbon fluxes. Earth Surface Processes and Landforms, 37(6): 642-655.

Dufour, A. and Bartram, J. (Eds.). (2012). Animal waste, water quality and human health. IWA publishing.

Earthscan. (2011). The state of the world's land and water resources for food and agriculture: Managing systems at risk, Routledge.

FAO (2013). Tool kit: reducing the food wastage footprint. Rome, Food and Agriculture Organization of the United Nations (FAO).

FAO (2015). Global initiative of food loss and waste. Rome, Food and Agriculture Organization of the United Nations (FAO).

FAO (2016). FAOSTAT. Database. Available at http://faostat3.fao.org/browse/R/RP/E Accessed August 2020. Rome, Food and Agriculture Organization of the United Nations (FAO).

Grizzetti, B., Pretato, U., Lassaletta, L., Billen, G. and Garnier, J. (2013). The contribution of food waste to global and European nitrogen pollution. Environmental Science \& Policy, 33: 186-195.

Herbert, E.R., Boon, P., Burgin, A.J., Neubauer, S.C., Franklin, R.B., Ardón, M. and Gell, P. (2015). A global perspective on wetland salinization: ecological consequences of a growing threat to freshwater wetlands. Ecosphere, 6(10): 1-43.

Kummu, M., De Moel, H., Porkka, M., Siebert, S., Varis, O. and Ward, P.J. (2012). Lost food, wasted resources: Global food supply chain losses and their impacts on freshwater, cropland, and fertiliser use. Science of the Total Environment, 438: 477-489.

Lorenz, J.J. (2014). A review of the effects of altered hydrology and salinity on vertebrate fauna and their habitats in northeastern Florida Bay. Wetlands, 34(1): 189-200.

Mateo-Sagasta, J. and Burke, J. (2010). Agriculture and water quality interactions: a global overview. SOLAW Background Thematic Report-TR08. Food and Agriculture Organization of the United Nations.

OECD (2008). Environmental performance of agriculture in OECD countries since 1990. Paris, Organisation for Economic Co-operation and Development (OECD).

OECD (2012). New and emerging water pollutants arising from agriculture, prepared by Alistair B.A. Boxall. Paris, Organisation for Economic Co-operation and Development (OECD) Publishing.

Purnell, J.Q., Gernes, R., Stein, R., Sherraden, M.S. Knoblock-Hahn, A. (2014). A systematic review of financial incentives for dietary behavior change. Journal of the Academy of Nutrition and Dietetics, 114(7): 1023-1035.

Schreinemachers, P. and Tipraqsa, P. (2012). Agricultural pesticides and land use intensification in high, middle- and low-income countries. Food Policy, 37(6): 616-626.

Steinfeld, H., Gerber, P., Wassenaar, T.D., Castel, V., Rosales, M., Rosales, M. and de Haan, C. (2006). Livestock's long 
shadow: environmental issues and options. Food \& Agriculture Org.

Thebo, A.L., Drechsel, P., Lambin, E.F. and Nelson, K.L. (2017). A global, spatially-explicit assessment of irrigated croplands influenced by urban wastewater flows. Environmental Research Letters, 12(7): 074008.

UNEP (2016). A snapshot of the world's water quality: towards a global assessment. Nairobi, United Nations Environment Programme (UNEP).

USEPA (2003). National management measures to control nonpoint source pollution from agriculture. Washington, DC, United States Environmental Protection Agency (US EPA).

Van Weert, F., Van der Gun, J. and Reckman, J. (2009). Global overview of saline groundwater occurrence and genesis. International Groundwater Resources Assessment Centre.

WHO (2012). Animal waste, water quality and human health. Geneva, Switzerland, World Health Organization.

WRI (2008). Eutrophication and hypoxia in coastal areas: a global assessment of the state of knowledge. WRI Policy Note. Washington, DC, World Resources Institute (WRI).

WWAP (2017). The United Nations World Water Development Report : Wastewater, the untapped resource. United Nations

World Water Assessment Programme (WWAP). Paris, United Nations Educational, Scientific and Cultural Organization.

$* * * * *$

Cite this chapter as: Chaturvedi, G., Chakraborty, M. and Ardeep (2020). Impacts of agricultural pollutants on water resources and their management. In: Advances in Environmental Pollution Management: Wastewater Impacts and Treatment Technologies, Volume 1, Eds. Kumar, V., Kamboj, N., Payum, T., Singh, J. and Kumar, P., pp. 29-40, https://doi.org/10.26832/aesa-2020-aepm-03 